\title{
Restructuring plans could revitalize museums' role
}

Parliament's standing committee on arts, culture, science and technology recently visited the South African Astronomical Observatory at Sutherland. Having explained the importance of its work, Bob Stobie, its director, was upset to find that the main interest of the committce members was to engage him in a debate about astrology.

The anecdote indicates that many South African politicians appear as ignorant of science as their constituents. One potential remedy for the problem of scientific illiteracy lies in museums. Over the past decade, most of the country's natural history museums have developed outreach programmes, both to target adult education and to supplement school curricula.

Yet a white paper on arts and culture, approved by the cabinet in September, fails to address either the future of South Africa's natural history museums, or the foundation of a national museum on science and technology, which many feel might at least start addressing public ignorance.

But the paper does acknowledge that the national status of the 18 museums currently funded by subsidies from the Department of Arts, Culture, Science and Technology (DACST) - with a total value of only R49 million - needs to be reviewed. Many are not really national institutions - their status was elevated by the previous government for political reasons. After two-and-a-half years of government procrastination on museums, Themba Wakashe, chief director in the DACST responsible for museums, concedes that "a decision has to be made, as the museum world is demoralized".

Five of these institutions have major natural history collections, as do at least five provincial museums and one municipal museum - the Durban Museum of Natural
Science - which is the country's most popular museum. In addition, large collections of insects, nematodes, fungi and arachnids are held by the Agricultural Research Council.

Apart from the fragmentation of collections, one of the main problems facing the muscums is that, with a few exceptions, their displays are outdated and lack information content. A rationalization survey conducted for the department by consultants Deloitte and Touche found them to be overmanaged in terms of posts. But perhaps even more critical is that most are in desperate need of new management blood. Restructuring might at least allow for new management to be brought in, with a brief to focus on the development of display programmes.

The report favours the model proposed last year by the Arts and Culture Task Group (ACTAG) of having two national museums, including natural history, in each of the country's twin capitals of Cape Town and Pretoria. But it has attracted criticism from biologists, who fear that this would result in downgrading the status of biological collections of national importance lying outside these two centres (see Nature 377, 5; 1995).

Non-national museums have been included in a review of all the country's museums, which has recently been completed, according to Wakashe. This task was undertaken by a four-member panel which included Wakashe himself.

Their recommendations were considered last week by the council of (provincial) ministers of arts and culture. They are now discussing the recommendations with the provincial governments, and there are strong indications that the provinces are going to be reluctant to relinquish their important collections to the national museums.

An additional decision has to be made on the foundation of a national museum of science and technology, suggested by ACTAG. There is already debate over its possible location. One suggestion is that it could be accommodated in some of the empty buildings that housed the now-defunct facilities at Pelindaba where the Atomic Energy Corporation enriched uranium for nuclear devices and "commercial purposes".

The corporation's chief executive, Waldo Stumpf, is amenable to the idea, but questions whether the location, $25 \mathrm{~km}$ west of Pretoria, would be optimal for attracting a large number of visitors.

\section{International links help to overcome years of isolation}

THERE are several bright spots in the gloom that currently envelops much of South African science. One is that, as a result of the decision to abandon apartheid, the country is now emerging from a prolonged period of international isolation, both scientific and otherwise.

Foreign scientists are flocking to the country, both as visitors and as researchers. Some of the more prominent individuals in the first category have included both the immediate past and present presidents of Britain's Royal Society, Sir Michael Atiyah and Sir Aaron Klug, and Walter Massey, former director of the US National Science Foundation (NSF), who suggested to a South African audience last month that science could serve as a "cultural glue" to unite its multicultural society.

A number of bilateral co-operative agreements have been signed since the ending of apartheid with countries such as the United Kingdom, France, the United States and Germany. Many foreign sources of research and travel funds are becoming available to South African scientists for the first time, including European Union and Commonwealth Science Council funding.

Some Western research funding bodies have deliberately chosen to allocate funds to promote South African science, partly in the hope that this will have a broader impact on the region. Britain's Wellcome Trust, for example, has targeted South Africa because it "sees the country as providing it with a collaborative base for development in the developing African continent", according to Michael Wilkinson, its international scientific programme manager.

Wellcome has introduced a range of grant and fellowship schemes for collaborative exchanges between South Africa and the United Kingdom. The trust is also currently considering applications from four institutions in southern Africa to host a new Wellcome Centre for Population Studies. Other support from Britain hascome in the form of a promise of five years' funding from the Royal Society to help build up research capacity in historically disadvantaged institutions.

Meanwhile, several senior administrators from the NSF have recently visited South Africa to discuss closer collaboration with US scientists. No specific funds are being set aside for this, but NSF officials say that proposals from US researchers for collaborative research projects are being actively encouraged. $\square$ 